\title{
RICE HERBICIDE MONITORING IN TWO BRAZILIAN RIVERS DURING THE RICE GROWING SEASON
}

\author{
Enio Marchesan ${ }^{1}$; Renato Zanella ${ }^{2}$; Luis Antonio de Avila ${ }^{1 *}$; Edinalvo Rabaioli Camargo ${ }^{1}$; \\ Sérgio Luiz de Oliveira Machado ${ }^{3}$; Vera Regina Mussoi Macedo ${ }^{4}$ \\ ${ }^{I} U F S M / C C R$ - Depto. de Fitotecnia - 97105-900 - Santa Maria, RS - Brasil. \\ ${ }_{3}^{2} U F S M / C C R$ - Depto. de Química, Lab. de Análise de Resíduos de Pesticidas. \\ ${ }^{3}$ UFSM/CCR - Depto. de Defesa Fitossanitária. \\ ${ }^{4}$ IRGA - Estação Experimental do Arroz, Av. Bonifácio Carvalho Bernardes, 1494 - 94930-030 - Cachoeirinha, \\ $R S$ - Brasil. \\ *Corresponding author <luis-avila@smail.ufsm.br>
}

\begin{abstract}
Irrigated rice production can involve environmental contamination with pesticides due to the proximity of the fields to rivers and to management problems. During three years (2000 to 2003) the rice herbicides clomazone, propanil and quinclorac were quantified in water during the rice growing season, in the Vacacaí and Vacacaí-Mirim Rivers, located in Rio Grande do Sul (RS) State, Brazil. Water samples were taken at several locations in each river, selected by their importance in terms of rice drainage area. The samples were analyzed by HPLC-UV. At least one herbicide was detected in $41 \%$ of the samples from the Vacacaí River and 33\% from the Vacacaí-Mirim River. The most frequent herbicide in both rivers and in each year was clomazone. The amount of herbicides in the river water was dependent on the rainfall regime. River water contamination by rice herbicides is probably caused by the rice water management used in the fields. The maintenance of flooded areas makes herbicides prone to contaminate the environment. To reduce the environmental contamination risk it is necessary to adopt measures to avoid overflow of flooded rice fields, keeping paddy water in the field for time enough to reduce the herbicide concentration before its release and enhancing the quality of the levees to reduce the probability of paddy rice overflow. Key words: clomazone, environmental impact, pesticides, propanil, quinclorac
\end{abstract}

\section{MONITORAMENTO DE HERBICIDAS EM DOIS RIOS BRASILEIROS DURANTE O PERÍODO DE CULTIVO DO ARROZ}

\begin{abstract}
RESUMO: No cultivo de arroz irrigado a possibilidade de contaminação dos mananciais hídricos é ampliada pelas características peculiares das áreas e do sistema de produção. Um estudo de monitoramento foi conduzido durante três anos (2000 a 2003), nos rios Vacacaí e Vacacaí-Mirim, localizados no Estado do Rio Grande do Sul, Brasil, buscando quantificar os herbicidas clomazone, propanil e quinclorac durante o período de cultivo do arroz. As amostras de água foram coletadas em vários locais em cada rio. Os locais de coleta foram selecionados pela importância em termos da captação da água de drenagem. As amostras foram analisadas por HPLC-UV. Herbicidas foram detectados nas águas dos rios durante no período de cultivo do arroz. Foi detectada a presença de pelo menos um herbicida em $41 \%$ das amostras no rio Vacacaí e $33 \%$ das amostras no rio Vacacaí-Mirim. O herbicida clomazone, foi detectado com maior freqüência nos dois rios. A quantidade de herbicida nas águas dos rios foi dependente do regime de chuva. A contaminação das águas dos rios pelos herbicidas utilizados no arroz provavelemente é decorrente do manejo de água adotado na região. A manutenção de áreas inundadas propicia a contaminação do ambiente por herbicidas. Para reduzir o risco de contaminação ambiental faz-se necessário à adoção de medidas que evitem a saída e liberação da água com resíduo das áreas de cultivo, mantendo-a na lavoura durante o tempo suficente para a redução da concentração do herbicida. A probabilidade de extravasamento pode ser reduzida com a melhor construção das taipas-ronda.

Palavras-chave: clomazone, impacto ambiental, pesticida, propanil, quinclorac
\end{abstract}

\section{INTRODUCTION}

Agrochemical use in agriculture leads to increasing crop yield and profits. However, their excessive use or misuse can cause environmental contamination of surface and ground water that can occur by drift, runoff, drainage and leaching (Cerejeira et al., 2003). Several surface water monitoring programmes have been carried out to quantify the degree of contamination by pesticides (Kammerbauer \& Moncada, 1998; Huber et al., 2000; Kolpin et al., 2000; Bouman et al., 2002; Cerejeira et al., 2003; Martínez et al., 2003). 
Rice crop conducted under flooded conditions is pointed out as being an activity of high pollution potential (FEPAM, 2004). The factors that contribute to this claim are the large amount of water used to maintain the flood (Machado et al., 2006), the usual proximity of the fields to surface water bodies, the predominant shallow aquifer in these areas, and the intentional and unintentional release of water from the field.

The rice production in Brazil demands intense agrochemical use, mainly herbicides, insecticides and fertilizers (Noldin et al., 2001). Among the rice herbicides registered in Brazil, three mostly used are clomazone, propanil and quinclorac. Clomazone is moderately mobile in sandy soils and its half-life in soils is approximately 24 hours (Vencill, 2002). Studies show that the clomazone concentration in soil solution is dependent on the amount of carbon and water in the soil (Lee et al., 2004) and its persistence in rice field is 28 days in the Rio Grande do Sul State (RS) conditions (Machado et al., 2003). Propanil is weakly adsorbed by the soil, is moderately mobile in sandy soils and of low mobility in clayey soils, with half-life of 1 to 3 days (Vencill, 2002). Studies on the persistence of propanil in irrigated rice conditions showed that its dissipation occurs within 24 hours and that the amount of dissipated propanil corresponds to the concentration of 3,4-dichloroaniline (DCA), indicating biological degradation of propanil to DCA (Deul et al., 1977). Quinclorac has variable mobility depending on soil type and organic matter and it can persist in the soil for one year affecting susceptible crops in rotation programs (Vencill, 2002). Conversely, studies under the conditions of the RS state demonstrated that quinclorac persists in detectable concentrations for 21 days in rice paddy water (Machado et al., 2003).

Therefore, the characteristics of rice fields, the climate conditions and the use of pesticides contribute to the enhanced risk of surface water contamination, justifying the need to quantify their degree of occurrence, to implement measures to prevent it. Thus, a three-year monitoring in the Vacacaí and VacacaíMirim river basins was carried out aiming to quantify the presence of clomazone, propanil and quinclorac during the rice growing season and correlate them with the rainfall regime.

\section{MATERIAL AND METHODS}

\section{Chemicals}

Stock solutions of clomazone (99.6\%), propanil $(99.3 \%)$ and quinclorac $(99 \%)$ were prepared individually in methanol and stored at $-18{ }^{\circ} \mathrm{C}$. Herbicide water solubilities $\left(\mathrm{mg} \mathrm{L}^{-1}\right)$ are $1100(25 \mathrm{C}) ; 130$ $(25 \mathrm{C})$ and $0.065(20 \mathrm{C})$ for clomazone, propanil and quinclorac, respectively.

\section{Study Area}

The basins of the Vacacaí and Vacacaí-Mirim Rivers are located in the Depressão Central region of the Rio Grande do Sul (RS) State in southern Brazil (Figure 1). The eastern limit of the basins is the city of Cachoeira do Sul, $180 \mathrm{~km}$ far from the state capital Porto Alegre. The northern limits are the cities of Santa Maria and Restinga Seca; the western limit is São Gabriel and the southern, Caçapava do Sul (STE, 1998). The two basins have a total drainage area of

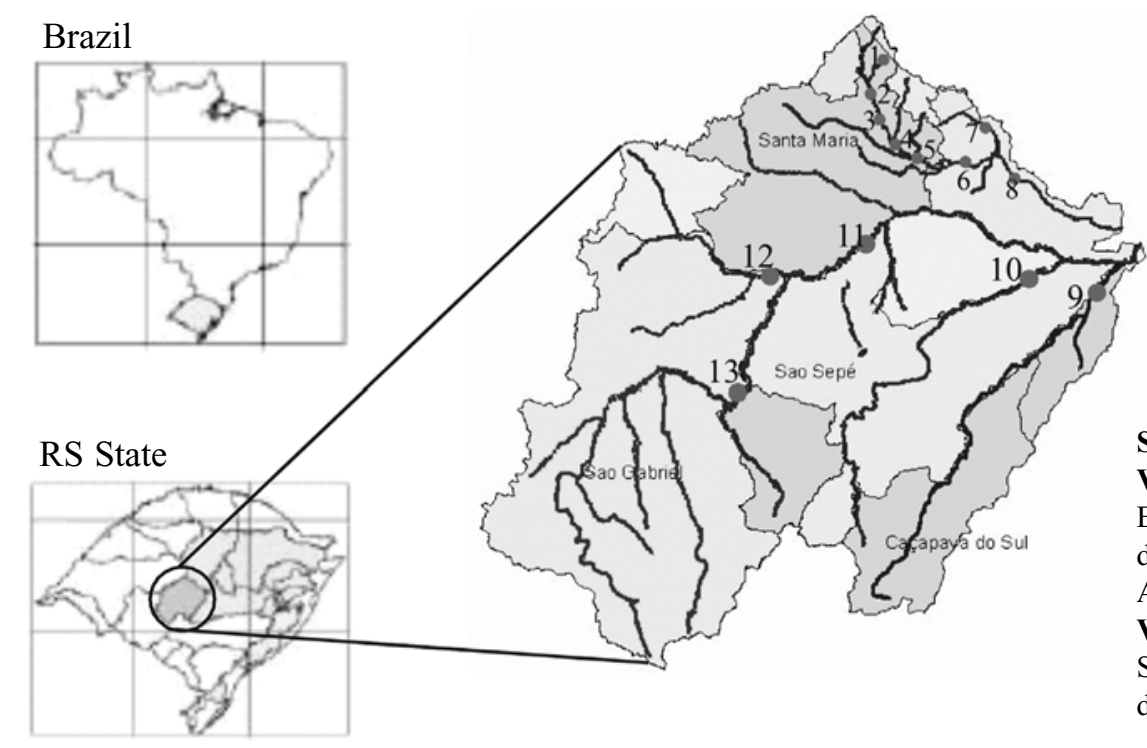

Sampling locations identification Vacacaí-Mirim River: Três Barras [1]; Envernadinha [2]; Arroio do Meio [3]; Ponte dos Bizzi [4]; RS-287 [5]; Arroio do Só [6]; Arroio da Divisa [7] and Restinga Seca [8]; Vacacaí River: Rio Santa Barbara [9]; Rio São Sepê [10]; Passo do Verde [11]; Passo da Lagoa [12] and Passo do Rocha [13].

Figure 1 - Sampling locations in the Vacacaí and Vacacaí-Mirim Rivers, Rio Grande do Sul State (RS), Brazil. 
$11,136 \mathrm{~km}^{2}$ and their cities have a total population of about 372,549 inhabitants (Rio Grande do Sul, 2002). In the river basins, irrigated rice is cultivated on about 85,000 ha. During the study 50 to $60 \%$ of the rice areas were treated with a tank mix of clomazone and propanil in post emergence, at rates of 350 and 1800 $\mathrm{g} \mathrm{ha}^{-1}$, respectively. Quinclorac was normally used at the rate of $375 \mathrm{~g} \mathrm{ha}^{-1}$ and mostly in the area of Rio Vacacaí-Mirim basin, on 10 to $15 \%$ of the rice area.

The Vacacaí-Mirim river basin is located between the cities of Santa Maria and Restinga Seca, with total length of $40 \mathrm{~km}$, and total drainage area of 1,136 $\mathrm{km}^{2}$ (Rio Grande do Sul, 2002). In this area, rice is produced, predominantly in small farms $(<50 \mathrm{ha})$, and cultivated in predominantly flat areas, in shallow soils with low natural drainage capacity.

\section{Sampling and sample treatment}

The monitoring was conducted during three years in the rice growing seasons (November to February, 2000/01, 2001/02 and 2002/03). In the Vacacaí basin, the monitoring was less detailed with less number of sampling points, with the objective of identifying the most critical locations. Conversely, in the Vacacaí-Mirim basin, the monitoring was more comprehensive, with a greater number of sampling points and done more frequent, with the objective of investigating the seasonal variation of herbicide concentration.

The Vacacaí River - In the first rice growing season $(2000 / 01) 15$ points along the river were sampled (Figure 1). These locations were previously selected by STE (STE, 1998). Water samples were taken at two different times: one in December 2000 and another in January 2001 (data not shown). These data were only exploratory. Based on the results, seven locations were selected according to their importance regarding rice water discharge; these points were sampled in the following two years (Figure 1). The location named Restinga Seca, located in the VacacaíMirim basin was sampled together with the Vacacaí River sampling locations. In the second rice growing season (2001/02), the sampling interval was 15 days, during the period between $12 / 02 / 00$ and $01 / 27 / 01$, which had greater intensity of herbicide application on the rice fields. An additional sampling was taken in the second half of February, to verify the persistence of the herbicides in the environment. In the third rice growing season (2002/03), the sampling period was a little late as compared with the previous years, 12/19/ 02 to $01 / 19 / 03$, due to the delay of rice planting caused by excessive rainfall. Two additional sampling times were included, one in the first half of November 2002 and the other in the first half of February 2003.
The Vacacaí-Mirim River - In the first rice growing season $(2000 / 01)$ water was collected from eight locations along the river (Figure 1). Water samples were taken every 4 days in the period between $11 / 26$ and $12 / 29$ and every 10 days from this date to $01 / 27$. In the second rice growing season (2001/02) five locations were sampled (Três Barras, Arroio do Meio, RS-287, Arroio do Só and Restinga Seca), with a seven-day interval between 11/28/01 and 01/27/02. In the third rice growing season $(2002 / 03)$ the same methodology as in the previous year was adopted, with samples between 12/19/02 and 02/03/03. Two additional samples were taken in the second half of February 2002 and 2003, also aiming to evaluate the herbicide persistence in the environment. In this river, the location called Três Barras was used as reference to the other locations, because apparently there was no rice farm upstream. However, some small vegetables, tobacco and corn farms were observed upstream.

At each sampling site a combined sample was obtained from sub-samples taken at three positions in the river profile: one in the center of the river and two close to the borders $(1 / 4$ of the river length from the margin) using a 2-liter PET bottle, with holes from the middle to the top of the bottle. The bottle was attached to a weight to collect water along the river profile in depth. The combined sample was dispensed in a clean glass bottle, closed and placed in a box with ice for transporting to the laboratory, for analysis. The glass bottles were washed with the cleaning solution $\operatorname{Extran}^{\circledR}$ and previously to each sampling, rinsed with river water.

\section{Extraction and analysis}

An aliquot of $250 \mathrm{~mL}$ was taken from each sample, acidified and filtered in C18 $(200 \mathrm{mg})$ cartridge previously conditioned for herbicide extraction. The herbicides were eluted with $2 \times 0.5 \mathrm{~mL}$ methanol (HPLC grade) and captured for future concentration. The solvent was evaporated to dryness using liquid nitrogen and the residues were re-suspended in $0.5 \mathrm{~mL}$ methanol (Zanella et al., 2002). The analysis was performed with a HPLC-UV using a C-18 column for separation and, methanol and water as mobile phase (Schlett, 1991; Font et al., 1993; Balinova, 1993).

\section{Quality control and assurance}

The average limit of detection and quantitation for each herbicide was respectively: 0.1 and $0.3 \mu \mathrm{g} \mathrm{L}^{-1}$ for clomazone; 0.072 and $0.22 \mu \mathrm{g} \mathrm{L}^{-1}$ for propanil and 0.03 and $0.09 \mu \mathrm{g} \mathrm{L}^{-1}$ for quinclorac. The $\mathrm{R}^{2}$ for the calibration curves for each herbicide was always above 0.999 . The herbicide recovery after fortification in four concentrations was between 88.9 and $107.5 \%$. 


\section{RESULTS AND DISCUSSION}

\section{Effect of years}

On average, at all sampling locations the percentage of contaminated samples varied between the rivers and among rice growing years (Table 1). From the total samples, 38,20 and $40 \%$ of them were contaminated with at least one herbicide in the first, second and third rice growing season, respectively. The differences among the years are related to the rainfall regime of each year. In Santa Maria, during December and January, the normal rainfall is $278.6 \mathrm{~mm}$, however in 2000/01 and 2002/03 the levels were 464 and $411 \mathrm{~mm}$, respectively (data not shown). This excess of rainfall could have caused rice fields to overflow, allowing greater amount of herbicides to reach the river. In addition, in 2001/02, a year with rainfall levels lower than the normal $189.6 \mathrm{~mm}$, only $20 \%$ of the samples were contaminated with herbicides.

In a rainy period, the time available for herbicide application is reduced, so the probability of environmental contamination increases because the herbicide concentration is greater and can easily be carried by water. The amount of pesticides reaching the sur- face and ground water is dependent of the herbicide characteristics, such as water solubility, partitioning and soil persistence, as well as land topography and rainfall regime (Martínez et al., 2003).

\section{Comparing the rivers}

Comparing the rivers, the Vacacaí River was the most contaminated one. On the average of all years, $41 \%$ of the samples of this river were contaminated with herbicide, while in the Vacacaí-Mirim River, 33\% of the samples were contaminated. In the Vacacaí River, average concentrations of 4.5 and $3.7 \mu \mathrm{g} \mathrm{L}^{-1}$ were observed for clomazone and propanil respectively. In 2002/2003, the maximum concentration was $8.9 \mu \mathrm{g} \mathrm{L}^{-1}$ and $11 \mu \mathrm{g} \mathrm{L}^{-1}$ for clomazone and propanil, respectively. The greater herbicide contamination in the Vacacaí River can be explained by the fact that this river has a larger drainage area and larger rice acreage than the Vacacaí-Mirim.

The guidelines for water quality in Brazil do not include the maximum allowed concentration for clomazone, propanil or quinclorac (CONAMA, 1986; Rio Grande do Sul., 1989). Limits for these products are not established in the USEPA legislation (USEPA, 2002) or in the Canadian legislation (CCME, 2002),

Table 1 - Surface water contamination by the herbicides clomazone, propanil and quinclorac in the Vacacaí and VacacaíMirim Rivers, Rio Grande do Sul State (RS), Brazil.

\begin{tabular}{|c|c|c|c|c|c|c|}
\hline \multirow[b]{2}{*}{ Years } & \multirow[b]{2}{*}{ Herbicides } & \multirow[b]{2}{*}{ Total number of samples } & \multirow[b]{2}{*}{$\% \mathrm{CS}^{1}$} & \multicolumn{3}{|c|}{ Concentration $\mu \mathrm{g} \mathrm{L}^{-1}$} \\
\hline & & & & Minimum & Average & Maximum \\
\hline & - & - & acaí Ri & - & - & ( \\
\hline \multirow[t]{4}{*}{$2001 / 02$} & Clomazone & 36 & 30 & 1.32 & 4.09 & 7.72 \\
\hline & Propanil & 36 & 17 & 1.08 & 1.76 & 3.94 \\
\hline & Quinclorac & 36 & 0 & -- & -- & -- \\
\hline & At least $1^{2}$ & 36 & 42 & & & \\
\hline \multirow[t]{5}{*}{$2002 / 03$} & Clomazone & 30 & 20 & 1.50 & 4.97 & 8.85 \\
\hline & Propanil & 30 & 20 & 0.72 & 5.59 & 11.0 \\
\hline & Quinclorac & 30 & 0 & -- & -- & -- \\
\hline & At least 1 & 30 & 40 & & & \\
\hline & - & - & aí-Mirin & r --.--- & ----- & - \\
\hline \multirow[t]{4}{*}{$2000 / 01$} & Clomazone & 104 & 27 & 0.41 & 1.34 & 5.62 \\
\hline & Propanil & 104 & 2 & 0.80 & 0.86 & 0.92 \\
\hline & Quinclorac & 104 & 13 & 0.48 & 1.57 & 6.60 \\
\hline & At least 1 & 104 & 38 & & & \\
\hline \multirow[t]{4}{*}{$2001 / 02$} & Clomazone & 45 & 11 & 1.24 & 2.38 & 4.82 \\
\hline & Propanil & 45 & 7 & 1.31 & 4.98 & 7.34 \\
\hline & Quinclorac & 45 & 9 & 1.87 & 2.79 & 3.81 \\
\hline & At least 1 & 45 & 20 & & & \\
\hline \multirow[t]{4}{*}{$2002 / 03$} & Clomazone & 45 & 20 & 0.62 & 2.17 & 5.10 \\
\hline & Propanil & 45 & 24 & 0.58 & 5.62 & 12.9 \\
\hline & Quinclorac & 45 & 0 & -- & -- & -- \\
\hline & At least 1 & 45 & 40 & & & \\
\hline
\end{tabular}

${ }^{1}$ Contaminated samples. ${ }^{2}$ Samples with the presence of at least one herbicide. 
though these agencies legislations include a vast number of organic substances. Conversely, the European Union, based on the water quality threshold established by the EU Drinking Water Directive, sets the maximum admissible concentration (MAC) of $0.1 \mu \mathrm{g} \mathrm{L}^{-1}$ for an individual pesticide and of $0.5 \mu \mathrm{g} \mathrm{L}^{-1}$ for total pesticide concentration in any sample of drinking water, except for aldrin, dieldrin, heptachlor and heptachlor epoxide, which are each limited to $0.03 \mu \mathrm{g} \mathrm{L}^{-1}$ maximum level (Hamilton et al., 2003).

\section{Comparing herbicides}

Clomazone was detected with more frequency in both rivers, followed by propanil and quinclorac, with frequencies of $21.6,14$ and $4.4 \%$ of the samples, respectively. The greater frequency of clomazone can be explained by the high utilization of this product in the region and by the relatively high herbicide persistence in water (Quayle, 2003). These characteristics allow the maintenance of high concentrations of this herbicide in the rice field enhancing the possibility of environmental contamination. Results from an herbicide persistence experiment in rice fields conducted in the Rio Grande do Sul state showed that clomazone was the most persistent when compared with propanil and quinclorac; clomazone was detected for up to 28 days after the herbicide application (Machado et al., 2003). Based on their results, these authors suggested the need for water to be kept in the field for 28 days after herbicide application to avoid environmental contamination. Clomazone is more persistent than propanil, because it has a half-life in the soil of approximately three weeks (Zanella et al., 2000) while propanil is fast metabolized to DCA in the rice fields, with a half-life of approximately one day (Perera et al., 1999).
Quinclorac was not detected in the Vacacaí River, probably because it is used over a smaller acreage as compared to propanil and clomazone; these two herbicides are used alone or in mixture to control grasses in rice. Contrary to our results, in a study carried out in the state of Santa Catarina, Deschamps et al. (2003) found that quinclorac was the most frequent herbicide, in part due to the highest use of quinclorac in that area.

\section{Sampling locations}

At the location called Três Barras, used as reference, quinclorac was detected in only $0.9 \%$ of the samples collected early in the growing season of 2000/ 01 , and in the other locations quinclorac was detected in 3.8 to $7.7 \%$ of the samples (Table 2). In the following year pesticides were not detected in Três Barras, however in the other locations herbicides were detected in 2.2 to $6.7 \%$ of the samples. In $2002 / 03$, at Três Barras, propanil and clomazone were detected in 2.2 and $6.7 \%$ of the samples, 1 and 3 samples, respectively, which probably came from a 2 ha rice field in which the mixture was applied in the last half of December. At Vacacaí location a steady pesticide detection was observed along the river, with similar percentage of contaminated samples among the sampling locations. There was no trend of increase or decrease of herbicide occurrence along the river.

\section{Seasonal variation}

The seasonal variation of water contamination (Figure 2) shows that the concentration of pesticides varied with the growing season and rainfall. In 2000/ 01 , approximately $75 \%$ of the contaminated samples occurred in December. However, in 2001/02 more than $65 \%$ of the contaminated samples were detected in the

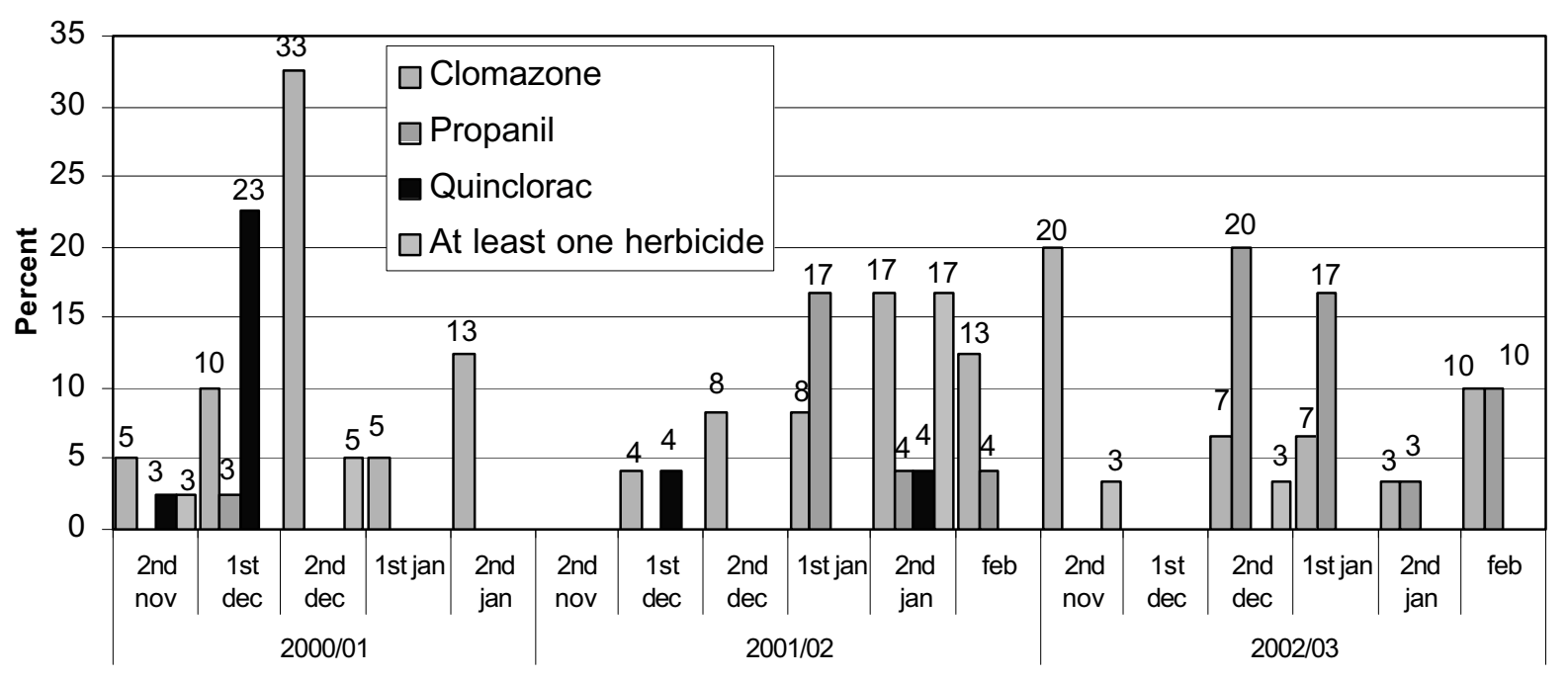

Figure 2 - Percent of samples with herbicide contamination in half $\left(1^{\text {st }}\right.$ and $\left.2^{\text {nd }}\right)$ of each month $($ Nov $=$ November, Dec $=$ December, Jan $=$ January, Feb $=$ February), during the studied period (Average of rivers). Rio Grande do Sul, Brazil. 
Table 2 - Percentage of samples with residues of clomazone, propanil and quinclorac at each sampling location in the Vacacaí and Vacacaí-Mirim Rivers, Rio Grande do Sul State (RS), Brazil.

\begin{tabular}{|c|c|c|c|c|c|c|c|c|c|c|c|c|}
\hline \multirow{3}{*}{ Sampling locations } & \multicolumn{4}{|c|}{$2000 / 01$} & \multicolumn{4}{|c|}{$2001 / 02$} & \multicolumn{4}{|c|}{$2002 / 03$} \\
\hline & \multicolumn{4}{|c|}{ Herbicides $^{1}$} & \multicolumn{4}{|c|}{ Herbicides } & \multicolumn{4}{|c|}{ Herbicides } \\
\hline & $\mathrm{C}$ & $\mathrm{P}$ & $\mathrm{Q}$ & $\mathrm{T} 1$ & $\mathrm{C}$ & $\mathrm{P}$ & $\mathrm{Q}$ & $\mathrm{T} 1$ & $\mathrm{C}$ & $\mathrm{P}$ & $\mathrm{Q}$ & $\mathrm{T} 1$ \\
\hline & \multicolumn{12}{|c|}{ Vacacaí River } \\
\hline & -- & $\cdots$ & -- & --- & --- & $\%--$ & & & & & & 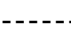 \\
\hline Passo do Verde & -- & -- & -- & -- & 5.6 & 2.8 & 0 & 8.3 & 10 & 3.3 & 0 & 13.3 \\
\hline Passo da Lagoa & -- & -- & -- & -- & 2.8 & 2.8 & 0 & 5.6 & 3.3 & 3.3 & 0 & 6.7 \\
\hline Passo do Rocha & -- & -- & -- & -- & 8.3 & 2.8 & 0 & 8.3 & 3.3 & 0 & 0 & 3.3 \\
\hline Rio São Sepé & -- & -- & -- & -- & 5.6 & 2.8 & 0 & 5.6 & 0 & 6.7 & 0 & 6.7 \\
\hline Rio Santa Bárbara & -- & -- & -- & -- & 2.8 & 2.8 & 0 & 5.6 & 3.3 & 3.3 & 0 & 6.7 \\
\hline Restinga Seca & -- & -- & -- & -- & 5.6 & 2.8 & 0 & 8.3 & 0 & 3.3 & 0 & 3.3 \\
\hline \multirow[t]{2}{*}{ Total } & -- & -- & -- & -- & & & & 42 & & & & 40 \\
\hline & \multicolumn{12}{|c|}{ Vacacaí-Mirim River } \\
\hline Três Barras & 0 & 0 & 0.9 & 0.9 & 0 & 0 & 0 & 0 & 6.7 & 2.2 & 0 & 6.7 \\
\hline Envernadinha & 3.8 & 0 & 2.9 & 5.8 & NS & NS & NS & NS & NS & NS & NS & NS \\
\hline Arroio do Meio & 2.9 & 0 & 0.9 & 3.8 & 2.2 & 0 & 2.2 & 4.4 & 2.2 & 8.8 & 0 & 8.8 \\
\hline Ponte do Bizzi & 3.8 & 0.9 & 1.9 & 5.8 & NS & NS & NS & NS & NS & NS & $\mathrm{NS}$ & $\mathrm{NS}$ \\
\hline RS - 287 & 3.8 & 0 & 0.9 & 4.8 & 2.2 & 4.4 & 4.4 & 6.7 & 4.4 & 4.4 & 0 & 8.8 \\
\hline Arroio do Só & 4.8 & 0 & 0.9 & 5.8 & 2.2 & 0 & 2.2 & 2.2 & 4.4 & 6.7 & 0 & 11.1 \\
\hline Arroio da Divisa & 3.8 & 0 & 1.9 & 3.8 & NS & NS & NS & NS & NS & NS & NS & NS \\
\hline Restinga Seca & 3.8 & 0.9 & 2.9 & 7.7 & 4.4 & 2.2 & 0 & 6.7 & 2.2 & 2.2 & 0 & 4.4 \\
\hline total & & & & 38 & & & & 20 & & & & 40 \\
\hline
\end{tabular}

${ }^{1}$ C: clomazone, P: Propanil, Q: Quinclorac and T1: Samples with presence of at least one herbicide. --Samples used just to select the locations to be used in the following years. NS Locations not sampled.

last half of January. This fact can be explained by the low rainfall intensity during December, which allowed the herbicides to stay in the rice field for a longer time. In contrast, the occurrence of $101.3 \mathrm{~mm}$ in the last half of January, promoted large amounts of runoff and allowed more herbicides to reach the river.

In late December 2002, a large amount of propanil was detected with concentration of up to 12 $\mu \mathrm{g} \mathrm{L^{-1 }}$ in three locations of the river, with maximum of $12.9 \mu \mathrm{g} \mathrm{L}^{-1}$. A severe rainfall of $108.4 \mathrm{~mm}$ between December 20th and 24th can explain this event. In this period producers observed that due to the high intensity of rainfall there was overload of the levees destroying many of them, allowing a large amount of water to reach the river.

The seasonal variation found in this experiment is similar to other found in the literature. The surface water pollution by pesticides is dependent on the agricultural activity, with high concentrations during the crop season (Martínez et al., 2003). The amount of pesticides transported to the surface water bodies depends on several factors, including not only soil characteristics, topography, time of application, agricultural practices and chemical properties of each pesticide (Leonard, 1990), but also on the rate of application, its chemical characteristics and the environmental conditions during application (Huber et al., 2000).

\section{CONCLUSIONS}

Clomazone, propanil and quinclorac were detected in both rivers during all rice growing seasons. Their concentrations were dependent on the rainfall regime.

The Vacacaí river was the most contaminated, because it has larger drainage and larger rice acreage area than the Vacacaí-Mirim; $41 \%$ and $33 \%$ of the samples were contaminated in the Vacacaí River and Vacacaí-Mirim River, respectively. Clomazone was the most frequent, followed by propanil and quinclorac. 
Actions need to be taken to avoid or reduce the herbicide transport to the rivers. In order to accomplish this, it is necessary to avoid or reduce water runoff from the fields for a period of at least the length of the herbicide persistence. This can be achieved by improving water management and enhancing levees quality to reduce the overflow of the fields in case of excessive rainfall.

\section{ACKNOWLEDGEMENTS}

To the Instituto Riograndense do Arroz (IRGA) and FAPERGS for financial support and the student's salaries, respectively.

\section{REFERENCES}

BALINOVA, A. Solid-phase extraction followed by high-performance liquid chromatographic analysis for monitoring herbicides in drinking water. Journal of Chromatography, v.643, p.203-207, 1993.

BOUMAN, B.A.M.; CASTAÑEDA, A.R.; BHUIYAN, S.I. Nitrate and pesticide contamination of groundwater under rice-based cropping systems: past and current evidence from the Philippines. Agriculture Ecosystem and Environment, v.92, p.185-199, 2002.

CANADIAN COUNCIL OF MINISTERS OF THE ENVIRONMENT - CCME. Publications. Canadian Environmental Quality Guidelines. Hull, 2002. Available at: <http://www.ccme.ca/assets/pdf/ e1_062.pdf $>$ Accessed in: April 142004.

CEREJEIRA, M.J.; VIANA, P.; BATISTA, S. Pesticides in portuguese surface and ground waters. Water Research, v.37, p.1055-1063, 2003.

CONSELHO NACIONAL DO MEIO AMBIENTE - CONAMA. CONAMA Resolution n.20, July 18, 1986.

DESCHAMPS, F.C.; NOLDIN, J.A.; EBERHARDT, D.S.; HERMES, L.C.; KNOBLAUCH, R. Agrochemicals residues in water from rice production areas, in Santa Catarina State, Brazil. In: BRAZILIAN RICE CONGRESS, 3., Camboriú, 2003. Proceedings. Camboriú, 2003. p.683-685.

DEUL, L.E.; BROWN, K.W.; TURNER, F.C.; WESTFALL, D.G.; PRICE, J.D.; Persistence of propanil, DCA, and TCAB in soil and water under flooded rice culture. Environmental Quality, v.6, p.127132,1977

FUNDAÇÃO ESTADUAL DE PROTEÇÃO AMBIENTAL HENRIQUE LUIS ROESSLER - FEPAM.. Environmental licensing: Agriculture activity. Available at: http:// www.fepam.rs.gov.br> Accessed in: April 14, 2004.

FONT, G.; MAÑES, J.; MOLTÓ, J.C.; PICÓ, Y.; Solid-phase extraction in multi-residue pesticides analysis of water. Journal of Chromatography, v.642, p.135-161, 1993.

HAMILTON, D.J.; AMBRUS, A.; DIETERLE; R.M.; FELSOT, A.S.; HARRIS, C.A.; HOLLAND, P.T.; KATAYAMA, A.; KURIHARA, N.; LINDERS, J.; UNSWORTH, J.; WONG, S.-S. Regulatory limits for pesticide residues in water. Pure and Applied Chemistry, v.75, n. 8, p. 1123-1155, 2003

HUBER, A.; BACH, M.; FREDE, H.G. Pollution of surface waters with pesticides in Germany: modeling non-point source inputs. Agriculture Ecosystem and Environment, v.80, p.191-204, 2000.

KAMMERBAUER, J.; MONCADA, J. Pesticide residue assessment in three selected agricultural production systems in the Choluteca River Basin of Honduras. Environmental Pollution, v.103, p.171-181, 1998.

KOLPIN, D.W.; THURMAN, E.M.; LINHART, S.M. Finding minimal herbicide concentration in ground water? Try looking for their degradates. Science of the Total Environment, v.248, p.115-122, 2000 .
LEE, D.J.; SENSEMAN, S.A.; O’BARR, J.H.; CHANDLER, J.M.; KRUTZ, L.J.; MCCAULEY, G.N. Soil characteristics and water potential effects on plant-available clomazone in rice. Weed Science, 52, p.310-318, 2004

LEONARD, R.A. Título do capítulo. In: CHENG, H.H. (Ed.) Pesticides in the soil environment: Processes, impacts and modeling. Madison: SSSA, Soil Science of America, Madison, WI, 1990. p.303-349.

MACHADO, S.L.O.; ZANELLA, R.; MARCHEZAN, E.; PRIMEL, E.G.; GONCALVES, F.F.; VILLA, S.C.C.; MAZIERO, H. Herbicide persistence in rice paddy water. In: BRAZILIAN RICE CONGRESS, 3., Camboriú, 2003. Proceedings. Camboriú, 2003. p.692-694.

MACHADO, S.L.O.; MARCHEZAN, E.; RIGHES, A.A.; CARLESSO, R.; VILLA, S.C.C.; CAMARGO. E.R. Water use and nutrients and sediments losses on the initial water drainage on flooded rice. Ciência Rural, v.36, n.1, p.65-71, 2006.

MARTÍNEZ, R.C.; GONZALO. E.R.; LAESPADA, M.E.F.; SERONERO, L.C.; ROMÁN, F.J.S. Evolution over time of the agricultural pollution of waters in an area of Salamanca and Zamora (Spain). Water Research, v.37, p.928-938, 2003.

NOLDIN, J.A.; EDERHARDT, D.S.; DESCHAMPS, F.C.; HERMES, L.C. Strategies for water sampling for monitoring the rice enviromental impact. BRAZILIAN RICE CONGRESS, 2., Porto Alegre, 2001. Proceedings. Porto Alegre, 2001. p.760-762.

PERERA, A.; BURLEIGH, J.R.; DAVIS, C.B. Movement and retention of propanil $\mathrm{N}-(3,4$ dichlorophenyl) propanamide in a paddy-riverine wetland system in Sri lanka. Agriculture Ecosystem and Environment, v.72, p.255-263, 1999

QUAYLE, W.C. Persistence of rice pesticides in floodwaters: influence of water management. In: INTERNATIONAL TEMPERATE RICE CONFERENCE, 3., Punta del Este, Uruguay, 2003. Abstracts. Punta del Este, 2003. p.97.

RIO GRANDE DO SUL (Estado). Secretaria de Saúde e Meio Ambiente do Estado do Rio Grande do Sul - SSMA. Portaria n. 05/89 de 16 de março de 1989. Aprova a Norma Técnica que dispõem sobre critérios e efluentes líquidos... Diário Oficial, Porto Alegre, RS, Brasil, 29 de março de 1989.

RIO GRANDE DO SUL (Estado). Secretaria Estadual do Meio Ambiente - SEMA. Current situation of the water resources in the Rio Grande do Sul State - Annual report. Porto Alegre: SEMA, 2002. $344 p$.

SCHLETT, C. Multi-residue-analysis of pesticides by HPLC after solid phase extraction. Journal of Analytical Chemistry, v.339, p.344347,1991

SERVIÇO TÉCNICO EM ENGENHARIA - STE. Evaluation of the demanded and available water in the Vacacaí River basin. Porto Alegre: UFRGS, Instituto de Pesquisas Hidráulicas, Departamento de Hidromecânica e Hidrologia, 1998. 220p.

USEPA. National recommended water quality criteria: 2002. Washington: EPA, 2002. 36p.

VENCILL, V.K. (Ed.) Herbicide handbook. 8.ed. Lawrence: Weed Science Society of America, 2002. 493p .

ZANELLA, R.; PRIMEL, E.G.; GONÇALVES, F.F.; MARTINS, A.F. Development and validation of a high-performance liquid chromatographic method for the determination of clomazone residues in surface water. Journal of Chromatography A, v.904, p. 257-262, 2000 .

ZANELLA, R.; PRIMEL, E.G.; MACHADO, S.L.O.; GONÇALVES, F.F.; MARCHEZAN, E. Monitoring of the herbicide clomazone in environmental water samples by solid-phase extraction and highperformance liquid chromatography with ultraviolet detection. Chromatographia, v.55, p.573-577, 2002.

Received January 09, 2006 Accepted March 02, 2007 